Sites of Violence 
This page intentionally left blank 


\title{
Sites of Violence
}

Gender and Conflict Zones

\author{
EDITED BY \\ Wenona Giles \\ and \\ Jennifer Hyndman
}

UNIVERSITY OF CALIFORNIA PRESS

Berkeley Los Angeles London 
University of California Press

Berkeley and Los Angeles, California

University of California Press, Ltd.

London, England

(C) 2004 by

The Regents of the University of California

Library of Congress Cataloging-in-Publication Data

Sites of violence : gender and conflict zones / edited by Wenona Giles and Jennifer Hyndman.

p. $\quad \mathrm{cm}$.

Includes bibliographical references and index.

ISBN 0-520-23072-8 (alk. paper). - ISBN o-520-23791-9 (pbk. : alk. paper)

1. Violence. 2. Political violence. 3. Social conflict. 4. Women -Crimes against. 5. Sex role. 6. Sex differences. 7. Feminist theory. I. Giles, Wenona Mary II. Hyndman, Jennifer.

$\mathrm{HM}^{2} 86 . \mathrm{S}_{5} 8 \quad 2004$

303.6-dc2 1

$200300845^{\circ}$

Manufactured in the United States of America

$\begin{array}{llllllllll}13 & 12 & 11 & 10 & 09 & 08 & 07 & 06 & 05 & 04\end{array}$

$\begin{array}{lllllllllll}11 & 10 & 9 & 8 & 7 & 6 & 5 & 4 & 3 & 2 & 1\end{array}$

The paper used in this publication is both acid-free and totally chlorine-free (TCF). It meets the minimum requirements of ANSI/ NISO Z39.48-1992 (R 1997) (Permanence of Paper).@ 